\title{
Kemampuan berpikir kreatif dan pemecahan masalah siswa melalui penerapan model project based learning
}

\author{
Rahmazatullaili, Cut Morina Zubainur, Said Munzir ${ }^{1}$
}

\begin{abstract}
Abstrak: Penelitian ini bertujuan mengetahui kemampuan berpikir kreatif dan pemecahan masalah siswa sesudah penerapan model Project based learning dibandingkan dengan sebelum penerapan model tersebut serta korelasi antara kemampuan berpikir kreatif dan pemecahan masalah. Penelitian ini merupakan penelitian eksperimen dengan desain penelitian one-group pretest-postest group design. Populasi penelitian ini adalah siswa Madrasah Tsanawiyah Swasta Darul Ulum Banda Aceh sedangkan sampel penelitian yaitu siswa kelas VIII2 sebanyak 30 siswa. Instrumen dalam penelitian ini terdiri atas tes kemampuan berpikir kreatif dan pemecahan masalah. Analisis data dilakukan secara kuantitatif menggunakan uji t yaitu Paired Samples TTest untuk pengujian perbedaan skor yang diperoleh siswa sebelum pembelajaran (pretes) dan setelah pembelajaran (postes). Hasil penelitian menunjukkan bahwa kemampuan berpikir kreatif dan pemecahan masalah siswa setelah penerapan model Project based learning lebih baik dari sebelum penerapan. Selain itu, terdapat hubungan antara kemampuan berpikir kreatif dan pemecahan masalah siswa yang belajar melalui penerapan model Project based learning. Hubungan kemampuan berpikir kreatif dan pemecahan masalah berada pada kategori cukup.
\end{abstract}

Kata kunci: Berpikir Kreatif; Pemecahan Masalah; Project based learning

\begin{abstract}
This research aims to understand the students' creative thinking and problem solving ability after implementing project based learning compared to before implementation and correlation between creative thinking and problem solving ability. It is an experiment research with one-group pretest-postest group design. The population is all students in Madrasah Tsanawiyah Swasta Darul Ulum Banda Aceh, 30 students are selected as samples. The instruments used are creative thinking and problem solving test. Data analysis used t-test, i.e. paired samples T-test to examine score difference before the implementation of project based learning (pretest) and after it (posttest). The result shows that creative thinking and problem solving
\end{abstract}

\footnotetext{
${ }^{1}$ Universitas Syiah Kuala, Aceh, Indonesia, rahma.mahira15@gmail.com
} 
ability after implementation is better than before it. In addition, there is a correlation between creative thinking and problem solving ability in 'enough' category.

Keywords: Creative Thinking; Problem Solving; Project Based Learning

\section{A. Pendahuluan}

Pembelajaran matematika disetiap jenjang pendidikan bertujuan membantu siswa memahami konsep yang dipelajari dan menerapkannya dalam berbagai situasi.Pembelajaran matematika diharapkan dapat membekali siswa dengan kemampuan berpikir logis, analitis, sistematis, kritis dan kreatif serta menumbuhkan kemampuan matematis lainnya (Depdiknas, 2006). Kemampuan berpikir kreatif merupakan salah satu kemampuan matematika yang dapat ditumbuhkan melalui proses pembelajaran matematika karena dalam menyelesaikan masalah matematika, siswa perlu memiliki kemampuan berpikir fleksibel yang merupakan salah satu aspek kemampuan berpikir kreatif. Kemampuan berpikir kreatif dapat diukur berdasarkan indikator kelancaran (fluency), kelenturan (flexibility), keaslian (originality), dan elaborasi (elaboration) (Dwijanto, 2007; Siswono, 2008).

Pembelajaran matematika dengan penyelesaian masalah dapat memberikan kesempatan kepada siswa untuk aktif menemukan ide yang dapat digunakan. Dalam Principles and Standards for School Mathematics, NCTM (2000) mengungkapkan bahwa kemampuan pemecahan masalah merupakan salah satu dari lima kemampuan yang perlu dimiliki oleh siswa disamping kemampuan penalaran, komunikasi, koneksi dan representasi. Pemecahan masalah merupakan suatu proses untuk mengatasi kesulitan yang ditemui untuk mencapai suatu tujuan yang diinginkan. Kemampuan pemecahan masalah merupakan salah satu komponen penting untuk mengembangkan kemampuan berpikir siswa, karena proses pembelajaran matematika pada dasarnya adalah penyelesaian masalah dan perlu mengaitkan materi yang sedang dipelajari dengan masalah-masalah yang ada dalam kehidupan sehari-hari serta menciptakan ide atau gagasan dalam berbagai cara. Menyelesaikan soal-soal pemecahan masalah selain 
memotivasi siswa untuk berpikir juga dapat menjadikan siswa lebih kreatif dan meningkatkan kemampuan matematisnya serta mengetahui kegunaan dari matematika sehingga diharapkan proses pembelajaran matematika lebih bermakna (Sumarmo, 2000).

Kemampuan berpikir kreatif dan kemampuan pemecahan masalah sangat dibutuhkan dalam menyelasaikan berbagai permasalahan. Pembelajaran matematika diharapkan dapat membekali siswa dengan kedua kemampuan tersebut. Kemampuan pemecahan masalah dapat diukur menggunakan langkah penyelesaian masalah menurut Polya (1985) yaitu memahami masalah, menyusun rencana, menjalankan rencana penyelesaian dan memeriksa kembali.

Pembelajaran matematika yang dilakukan guru terutama di Madrasah Tsanawiyah Swasta masih kurang memperhatikan kemampuan berpikir kreatif dan pemecahan masalah dalam pelaksanaan pembelajaran (Siswoyuono \& Susilo, 2016; Sari, Ikhsan, \& Saminan, 2017; Tasni \& Susanti, 2017). Masalah matematika yang disajikan kurang menantang, hanya menuntut jawaban tunggal. Hal ini seperti temuan Husna (2013) bahwa pembelajaran matematika yang dilakukan pada kebanyakan Madrasah Tsanawiyah Swasta Banda Aceh belum sepenuhnya dapat mengembangkan kemampuan tingkat tinggi matematis siswa seperti kemampuan pemecahan masalah. Amalia (2014) juga mengungkapkan bahwa siswa kurang dilatih mengerjakan soal yang berkaitan dengan pemecahan masalah.Pembelajaran lebih berfokus pada guru dan siswa kurang dilibatkan dalam menyelesaikan soal. Setelah guru membahas contoh soal dilanjutkan dengan siswa mengerjakan soal-soal latihan dengan langkah-langkah penyelesaian seperti contoh guru atau yang dikenal dengan alur opening-example-exercise-closing (Sembiring, Hadi \& Dolk, 2008; Wahyu, 2015). Siswa tidak pernah ditantang untuk mencoba dengan cara lain, atau cara siswa sendiri yang tetap logis. Hal ini mengakibatkan siswa kurang berminat dalam menyelesaikan soal-soal yang membutuhkan banyak strategi dan menganggap kemampuan berpikir kreatif dan pemecahan masalah bukanlah sesuatu yang penting dalam proses belajar.

Menyadari akan pentingnya kemampuan pemecahan masalah dan berpikir kreatif matematis siswa, maka diperlukan upaya untuk memperbaiki dan meningkatkan pembelajaran matematika, diantaranya 
melakukan inovasi dalam pembelajaran dengan menggunakan model atau pendekatan pembelajaran yang sesuai agar siswa dapat berlatih menggunakan kemampuannya dalam berpikir. Siswa perlu dilatih menyelesaikan permasalahan yang memberikan kesempatan untuk menggali kemampuannya mengemukakan ide atau strategi dalam menyelesaikan masalah. Salah satu pembelajaran yang memberi kesempatan kepada siswa untuk menemukan penyelesaian dari permasalahan dengan berbagai cara adalah model pembelajaran Project based learning (PjBL).

PjBL merupakan sebuah model yang mengatur pembelajaran melalui proyek-proyek tertentu (Thomas, 2000). Proyek-proyek adalah tugastugas yang diberikan guru berdasarkan pertanyaan atau masalah yang menantang, melibatkan siswa dalam perancangan, pemecahan masalah, memberikan keputusan, atau menyelidiki aktivitas, memberikan hak secara otonomi selama periode waktu untuk mengumpulkan dan mengintegrasikan pengetahuan baru berdasarkan pengalaman siswa dalam beraktifitas secara nyata (Yunianta, Rochmad \& Rusilowati, 2012).

Langkah dalam pelaksanaan PjBL yang digunakan dikembangkan berdasarkan beberapa teori (The George Lucas Educational Foundation, 2005). Langkah pelaksanaan PjBL dimulai dengan pertanyaan yang dapat memberi penugasan kepada siswa dalam melakukan aktivitas, yang kemudian dilakukan investigasi mendalam, seperti mengidentifikasi unsur yang ada dan yang ditanyakan.Selanjutnya mendesain perencanaan proyek dan penyusunan jadwal penyelesaian proyek, dimana perencanaan dilakukan secara kolaboratif antara guru dan siswa. Perencanaan berisi aturan pelaksanaan kegiatan, pemilihan aktivitas yang dapat mendukung dalam menjawab pertanyaan mendasar, dengan cara menggunakan berbagai metode atau sumber yang mungkin untuk membantu penyelesaian masalah serta membuat penjelasan tentang pemilihan cara/strategi menyelesaikan masalah, sehingga siswa diharapkan dapat memberikan banyak ide, cara atau saran serta siswa dapat menghasilkan beragam gagasan dan dapat melihat suatu masalah dari beragam sudut pandang/pemikiran.

Pembelajaran dengan PjBL, guru bertanggung jawab melakukan monitor terhadap aktivitas siswa selama menyelesaikan proyek, sehingga siswa mampu mengembangkan suatu gagasan dan menghasilkan hasil 
yang memuaskan. Menguji atau menilai hasil proyek juga perlu dilakukan untuk membantu guru dalam mengevaluasi kemajuan siswa dan memberi umpan balik tentang tingkat pemahaman yang sudah dicapai siswa.Hal ini juga dikarenakan guru sebagai fasilitator dalam pembelajaran PjBL (Yunianta, Rochmad \& Rusilowati, 2012). Pada akhir pembelajaran, perlu dilakukan refleksi terhadap aktivitas dan hasil proyek yang telah dilakukan dengan harapan dapat menerapkan dan menyelesaikan permasalahanpermasalahan lain dalam kehidupan sehari-hari.

Berdasarkan permasalahan di atas yaitu perlunya berpikir kreatif dan pemecahan masalah dalam pembelajaran matematika maka dilakukan penelitian tentang penerapan model PjBL dengan tujuan mengetahui kemampuan berpikir kreatif dan pemecahan masalah siswa sesudah penerapan model PjBL dibandingkan dengan sebelum penerapan model PjBL. Selain itu, untuk mengetahui sejauh mana kemampuan berpikir kreatif memberikan pengaruh terhadap kemampuan pemecahan masalah siswa.

\section{B. Metode Penelitian}

Penelitian ini merupakan penelitian kuantitatif dengan rancangan pre-tes pos-tes pada satu kelompok (One-Group Pre-Test Post-Test Design) mencakup satu kelompok yang diberikanperlakuan dengan model PjBL. Kelompok tersebut diberikan pretest dan postest dengan menggunakan instrumen tes yang setara. Pretest dilaksanakan sebelum pembelajaran dilakukan. Setelah perlakuan, siswa diberikan postest yang bertujuan untuk mengetahui peningkatan kemampuan berpikir kreatif dan pemecahan masalah. Populasi dalam penelitian ini adalah seluruh siswa MTs Darul Ulum Banda Aceh. Sampel dalam penelitian ini dipilih secara acak dan menetapkan siswa kelas VIII2 sebanyak 30 siswa sebagai sampel yang akan diberikan pembelajaran dengan model PjBL. Pembelajaran dilakukan dengan menerapkan model PjBL pada materi statistika selama 5 pertemuan.

Instrumen yang digunakan dalam penelitian ini berupa tes kemampuan berpikir kreatif dan tes kemampuan pemecahan masalah. Instrumen tes kemampuan berpikir kreatif dikembangkan dalam bentuk soal uraian dengan indikator kelancaran, kelenturan, keaslian dan elaborasi (Tabel 1). 
Tabel 1. Indikator Kemampuan Berpikir Kreatif

\begin{tabular}{|l|l|}
\hline Indikator berpikir kreatif & \multicolumn{1}{|c|}{ Deskripsi indikator } \\
\hline kelancaran (fluency) & $\begin{array}{l}\text { Kemampuan untuk menghasilkan banyak } \\
\text { gagasan }\end{array}$ \\
\hline kelenturan (flexibility) & $\begin{array}{l}\text { Kemampuan untuk mengemukakan bermacam- } \\
\text { macam pemecahan }\end{array}$ \\
\hline keaslian (Originality) & $\begin{array}{l}\text { Kemampuan memberikan gagasan yang relatif } \\
\text { baru dan jarang diberikan kebanyakan orang }\end{array}$ \\
\hline elaborasi (elaboration) & $\begin{array}{l}\text { Kemampuan merinci secara detail jawaban yang } \\
\text { dibuat }\end{array}$ \\
\hline
\end{tabular}

Tes kemampuan pemecahan masalah dikembangkan berdasarkan indikator kemampuan pemecahan masalah, diantaranya memahami masalah, menyusun rencana, menjalankan rencana pemecahan dan memeriksa kembali (Tabel 2). Soal yang telah dirancang dikonsultasikan kepada validator untuk divalidasi dengan tujuan agar terdapat kesesuaian antara soal dan indikator kemampuan yang diukur.

Tabel 2. Indikator Kemampuan Pemecahan Masalah

\begin{tabular}{|l|l|}
\hline Indikator pemecahan masalah & \multicolumn{1}{|c|}{ Deskripsi indikator } \\
\hline Memahami masalah & $\begin{array}{l}\text { Memahami masalah yang meliputi } \\
\text { menuliskan yang diketahui, yang ditanya, } \\
\text { cukup, kurang atau berlebihan hal-hal yang } \\
\text { diketahui untuk menyelesaikan soal }\end{array}$ \\
\hline Menyusun rencana & $\begin{array}{l}\text { Menyusun aturan-aturan atau tata urutan } \\
\text { kemungkinan pemecahan masalah, } \\
\text { menuliskan persamaan atau membuat } \\
\text { model matematika, menuliskan rumus yang } \\
\text { digunakan dan menuliskan langkah-langkah } \\
\text { penyelesaian sehingga tidak ada satupan } \\
\text { alternatif yang terabaikan }\end{array}$ \\
\hline $\begin{array}{l}\text { Menjalankan rencana } \\
\text { pemecahan }\end{array}$ & $\begin{array}{l}\text { Melakukan perhitungan atau penyelesaian } \\
\text { untuk menemukan solusi }\end{array}$ \\
\hline Memeriksa kembali & $\begin{array}{l}\text { Melakukan pemeriksaan kembali terhadap } \\
\text { proses dan solusi yang dibuat untuk } \\
\text { memastikan bahwa cara itu sudah baik dan } \\
\text { benar }\end{array}$ \\
\hline
\end{tabular}


Analisis data dilakukan secara kuantitatif untuk mengetahui besarnya peningkatan kemampuan berpikir kreatif dan pemecahan masalah serta korelasi antara kemampuan berpikir kreatif dan pemecahan masalah. Sebelum pengujian, skor yang diperoleh siswa terlebih dahulu dilakukan uji normalitas dan uji homogenitas untuk menentukan jenis uji statistik yang digunakan. Pengujian normalitas menggunakan Uji KolmogorovSmirnov dan uji homogenitas menggunakan Uji Levene dengan $\alpha=0,05$. Setelah diketahui berdistribusi normal dan homogen, maka pengujian dapat menggunakan uji parametrik.

Pengujian perbedaan skor yang diperoleh siswa sebelum tindakan (pretes) dan setelah tindakan (postes) menggunakan uji t yaitu Paired Samples T-Test mengingat sampel adalah subjek yang sama (one sample pretest-postest group) sehingga skor yang diperoleh memiliki korelasi (Sundayana, 2010). Pengujian untuk mengetahui hubungan kemampuan berpikir kreatif dan pemecahan masalah menggunakan uji regresi linear sehingga hasilnya bukan hanya dapat melihat hubungan kedua data juga sekaligus melihat seberapa besar sumbangan peningkatan kemampuan yang satu terhadap lainnya dengan signifikan $\alpha=0,05$. Hipotesis yang diuji dalam penelian ini,yaitu:

Hipotesis 1: Kemampuan berpikir kreatif siswa sesudah penerapan model Project based learning lebih baik dibandingkan sebelum penerapan.

$\mathrm{H}_{0}: \mu_{1}=\mu_{2}$ Kemampuan berpikir kreatif siswa sesudah penerapan model Project based learning tidak lebih baik dibandingkan sebelum penerapan.

Ha: $\mu_{1}>\mu_{2}$ Kemampuan berpikir kreatif siswa sesudah penerapan model Project based learning lebih baik dibandingkan sebelum penerapan.

Hipotesis 2: Kemampuan pemecahan masalah siswa sesudah penerapan model Project based learning lebih baik dibandingkan sebelum penerapan.

$\mathrm{H}_{0}: \mu_{1}=\mu_{2}$ Kemampuan pemecahan masalah siswa sesudah penerapan model Project based learning tidak lebih baik dibandingkan sebelum penerapan. 
Ha: $\mu_{1}>\mu_{2}$ Kemampuan pemecahan masalah siswa sesudah penerapan model Project based learning lebih baik dibandingkan sebelum penerapan.

Kriteria pengujian hipotesis berdasarkan $P$-Value (significance atau sig) adalah Jika sig $(1-$ tailed $)<\alpha$ dengan $\alpha=0,05$, maka $\mathrm{H}_{0}$ ditolak dan Ha diterima. Jika sig ( 1 - tailed) $\geq \alpha$ dengan $\alpha=0,05$, maka $\mathrm{H}_{0}$ diterima.

Hipotesis 3: Terdapat hubungan yang positif dan signifikan antara peningkatan kemampuan berpikir kreatif dan pemecahan masalah siswa dalam pembelajaran dengan model Project based learning.

Ho: $\rho=0$ Tidak terdapat hubungan yang positif dan signifikan antara peningkatan kemampuan berpikir kreatif dan pemecahan masalah siswa dalam pembelajaran dengan model Project based learning.

Ha: $\rho \neq 0$ Terdapat hubungan yang positif dan signifikan antara peningkatan kemampuan berpikir kreatif dan pemecahan masalah siswa dalam pembelajaran dengan model Project based learning.

\section{Temuan dan Pembahasan}

Adapun hasil penelitian yang diperoleh meliputi hasil pretes dan postes dari tes kemampuan berpikir kreatif dan pemecahan masalah. Analisis kemampuan berpikir kreatif terhadap data pretes dan postes akan dibahas berdasarkan indikator yang termuat dalam soal. Nilai rata-rata pretes siswa yang diperoleh pada indikator kelancaran adalah 1,73 dan nilai rata-rata postes adalah 3,53. Nilai rataan siswa pada indikator kelancaran mengalami peningkatan sebesar 102,3\%. Peningkatkan ini juga memberikan nilaiN-gain sebesar 0,74 yang berarti termasuk dalam kategori peningkatan tinggi. Pada indikator flexibility, diperoleh nilai pretes siswa adalah 1,73 dan postes 3,10. Rataan skor postes siswa meningkat menjadi 3,10 artinya meningkat sebesar 78,84\% dibandingkan skor rataan pretets. Peningkatkan ini juga memberikan nilai $\mathrm{N}$-gain sebesar 0,57 yang berarti termasuk dalam kategori peningkatan sedang.

Nilai rata-rata pada indikator kemampuan elaborasi yang diperoleh siswa sebelum tindakan diberikan (pretes) dan setelah tindakan diberikan (postes), terdapat peningkatan skor rataan dari 1,82 pada pretes menjadi 3,27 pada postes. Hal ini menunjukkan peningkatan sebesar $79,67 \%$ 
dibandingkan rataan skor yang diperoleh pada pretets. Peningkatan ini juga memberikan nilai $\mathrm{N}$-gain sebesar 0,66 yang berarti termasuk dalam kategori peningkatan sedang. Sedangkan pada indikator keaslian, nilai rata-rata siswa juga meningkat sebesar $59,0 \%$, yaitu dari 2,03 pada pretes menjadi 3,23 pada postes.Peningkatkan ini juga memberikan nilai $\mathrm{N}$-gain sebesar 0,62 yang berarti termasuk dalam kategori peningkatan sedang. Secara ringkas peningkatan N-Gain pada tiap indikator diberikan pada Tabel 3.

Tabel 3. Ringkasan Peningkatan Indikator Kemampuan Berpikir Kreatif

\begin{tabular}{|c|c|c|c|c|c|}
\hline No & Indikator & $\begin{array}{c}\text { Rataan } \\
\text { N- Gain Indikator }\end{array}$ & $\begin{array}{l}\text { Rataan } \\
\text { Pretes }\end{array}$ & $\begin{array}{l}\text { Rataan } \\
\text { Postes }\end{array}$ & $\begin{array}{l}\text { Rataan } \\
\text { N-Gain }\end{array}$ \\
\hline 1 & Fluency & 0,74 & \multirow{4}{*}{9,13} & \multirow{4}{*}{16,4} & \multirow{4}{*}{0,64} \\
\hline 2 & Flexibility & 0,57 & & & \\
\hline 3 & Originalitas & 0,62 & & & \\
\hline 4 & Elaborasi & 0,66 & & & \\
\hline
\end{tabular}

Tabel 3 menunjukkan skor 0,64 pada rataan $\mathrm{N}$-Gain keseluruhan indikator dapat dikatakan bahwa kemampuan berpikir kreatif siswa yang memperoleh pembelajaran dengan model PjBL meningkat dengan peningkatan sedang dan besarnya peningkatan kemampuan berpikir kreatif siswa terhadap rataan nilai pretes adalah sebesar $79,63 \%$.

Tabel 4. Hasil Uji Normalitas dan Homogenitas Kemampuan Berpikir Kreatif

\begin{tabular}{|l|c|c|}
\hline \multicolumn{1}{|c|}{ Pengujian } & Hasil Uji (sig) & Kesimpulan \\
\hline Normalitas Pretes & 0,128 & Normal \\
\hline Normalitas Postes & 0,050 & Normal \\
\hline Homogenitas & 0,175 & Homogen \\
\hline
\end{tabular}

Berdasarkan ringkasan hasil uji pada Tabel 4 dapat disimpulkan bahwa skor pretes dan postes kemampuan berpikir kreatif adalah berdistribusi normal dan homogen, maka selanjutnya dilakukan uji perbedaan rata-rata dari skor pretes dan postes. Pengujian beda kedua data tersebut menggunakan uji t yaitu Paired Samples T-Test mengingat sampel adalah subjek yang sama (one sample pretes-postes group) sehingga skor yang diperoleh memiliki korelasi. Pengujian menggunakan 
bantuan software SPSS 22 dengan signifikan $\alpha=0,05$. Dengan kriteria pengujian adalah jika $\mathrm{Sig}$ (1-tailed) $>$ a maka $\mathrm{H}_{\mathrm{o}}$ diterima dan jika Sig (1tailed) $<$ a maka $\mathrm{H}_{\mathrm{o}}$ ditolak dan $\mathrm{H}_{\mathrm{a}}$ diterima. Secara ringkas hasil uji perbedaan kemampuan berpikir kreatif ditunjukkan pada Tabel 5.

Tabel 5. Hasil Uji Perbedaan Kemampuan Berpikir Kreatif

\begin{tabular}{|c|c|c|c|}
\hline Pasangan & Nilai & Sig (2-tailed) & Sig(1-tailed) \\
\hline Pair 1 & Pretes \& Postes & 0,000 & 0,000 \\
\hline
\end{tabular}

Berdasarkan Tabel 5 dapat dilihat bahwa hasil uji menunjukan bahwasig(1-tailed) menunjukkan nilai $<0,05$. Pengambilan kesimpulan dengan merujuk nilai sig(1-tailed) dikarenakan hipotesis ini hanya menguji satu pihak saja yaitu nilai yang lebih besar (lebih baik) bukan menguji ada atau tidaknya perbedaan antara kedua data. Nilai sig(1-tailed) $=0,000<$ 0,05 memberi arti bahwa sig(1-tailed) < $\alpha$ yang menyebabkan ditolaknya $\mathrm{H}_{0}$ dan diterimanya $\mathrm{H}_{\mathrm{a}}$ yang berarti dapat disimpulkan bahwa kemampuan berpikir kreatif siswa sesudah penerapan model Project based learning lebih baik dibandingkan sebelum penerapan.

Analisis kemampuan pemecahan masalah terhadap data pretes dan postes akan dibahas berdasarkan indikator pemecahan masalah yang termuat dalam soal. Nilai rata-rata pretes siswa yang diperoleh pada indikator memahami masalah adalah 5,57 dan nilai rata-rata postes adalah 10,77 . Nilai rataan siswa pada indikator memahami masalah mengalami peningkatan sebesar 93,41\%. Peningkatkan ini juga memberikan nilaiN-Gain sebesar 0,81 yang berarti termasuk dalam kategori peningkatan tinggi. Pada kemampuan merencanakan penyelesaian, diperoleh nilai pretes siswa adalah 5,23 dan postes 10,6. Peningkatan kemampuan dari 5,23 menjadi 10,6 atau menjadi sebesar $102,54 \%$ menunjukan bahwa peningkatan kemampuan merencanakan penyelesaian yang dialami oleh siswa sangat signifikan. Hal tersebut juga dikuatkan dengan nilai $\mathrm{N}$-Gain sebesar 0,79 yang digolongkan dalam kategori peningkatan yang tinggi.

Nilai rata-rata pada indikator kemampuan menjalankan rencana pemecahan yang diperoleh siswa sebelum tindakan diberikan (pretes) sebesar 5,1 dan setelah tindakan diberikan (postes) sebesar 8,9 menunjukkan peningkatan sebesar $74,5 \%$ dengan $\mathrm{N}$-Gain sebesar 0,55 
menunjukan bahwa peningkatan kemampuan menjalankan rencana pemecahan masalah adalah signifikan dan digolongkan dalam kategori peningkatan sedang. Sedangkan pada kemampuan memeriksa kembali, nilai rata-rata siswa juga meningkat sebesar $35,81 \%$, yaitu dari 4,9 pada pretes menjadi 6,7 pada postes dengan $\mathrm{N}$-gain sebesar 0,389 menunjukan bahwa peningkatan kemampuan siswa dalam melakukan pemeriksaan kembali terhadap penyelesaian yang dilakukannya tidak terlalu signifikan dan termasuk kategori sedang, namun masih cenderung rendah. Hal tersebut dikarenakan siswa terlalu terfokus pada proses penyelesaian untuk menentukan hasil dan merasa puas dengan hasil yang diperoleh sehingga tidak membutuhkan pengecekan kemabali. Secara ringkas peningkatan N-Gain pada tiap indikator diberikan pada Tabel 6 .

Tabel 6. Ringkasan Peningkatan Indikator Kemampuan Pemecahan Masalah

\begin{tabular}{|c|c|c|c|c|c|}
\hline No & Indikator & $\begin{array}{c}\text { Rataan } \\
\text { N- Gain Indikator }\end{array}$ & $\begin{array}{l}\text { Rataan } \\
\text { Pretes }\end{array}$ & $\begin{array}{l}\text { Rataan } \\
\text { Postes }\end{array}$ & $\begin{array}{l}\text { Rataan } \\
\text { N-Gain }\end{array}$ \\
\hline 1 & Memahami & 0,81 & \multirow{4}{*}{20,83} & \multirow{4}{*}{46,26} & \multirow{4}{*}{0,74} \\
\hline 2 & Rencana & 0,79 & & & \\
\hline 3 & Menjalankan & 0,52 & & & \\
\hline 4 & Memeriksa & 0,39 & & & \\
\hline
\end{tabular}

Tabel 6 menunjukkan rataan 0,74 pada rataan N-Gain keseluruhan indikator dapatdikatakan bahwa kemampuan pemecahan masalah siswa siswa mencapai kategori tinggi dan besarnya peningkatan kemampuan pemecahan masalah siswa terhadap rataan nilai pretes adalah sebesar $91,8 \%$.

Tabel 7. Hasil Uji Normalitas dan Homogenitas Kemampuan Pemecahan Masalah

\begin{tabular}{|l|c|c|}
\hline Pengujian & Hasil Uji (sig) & Kesimpulan \\
\hline Normalitas Pretes & 0,186 & Normal \\
\hline Normalitas Postes & 0,191 & Normal \\
\hline Homogenitas & 0,200 & Homogen \\
\hline
\end{tabular}


Berdasarkan ringkasan hasil uji pada Tabel 7 dapat disimpulkan bahwa skor pretes dan postes kemampuan pemecahan masalah adalah berdistribusi normal dan homogen maka selanjutnya dilakukan uji perbedaan rata-rata dari skor pretes dan postes. Pengujian beda kedua data tersebut menggunakan uji t yaitu Paired Samples T-Test mengingat sampel adalah subjek yang sama (one sample pretes-postes group) sehingga skor yang diperoleh memiliki korelasi. Pengujian menggunakan bantuan software SPSS 22 dengan signifikan $\alpha=0,05$. Dengan kriteria pengujian adalah jika $\mathrm{Sig}$ (1-tailed)> $\alpha$ maka $\mathrm{H}_{\mathrm{o}}$ diterima dan jika Sig (1tailed) $<\alpha$ maka $\mathrm{H}_{\mathrm{o}}$ ditolak dan $\mathrm{H}_{\mathrm{a}}$ diterima. Secara ringkas hasil uji perbedaan kemampuan pemecahan masalah ditunjukkan pada Tabel 8.

Tabel 8. Hasil Uji Perbedaan Kemampuan Pemecahan Masalah

\begin{tabular}{|c|c|c|c|}
\hline Pasangan & Nilai & Sig (2-tailed) & Sig(1-tailed) \\
\hline Pair 1 & Pretes \& Postes & 0,000 & 0,000 \\
\hline
\end{tabular}

Berdasarkan tabel di atas dapat dilihat bahwa hasil uji menunjukkan bahwa sig(1-tailed) menunjukkan nilai $<0,05$. Pengambilan kesimpulan dengan merujuk nilai sig(1-tailed) dikarenakan hipotesis ini hanya menguji satu pihak saja yaitu nilai yang lebih besar (lebih baik) bukan menguji ada atau tidaknya perbedaan antara kedua data. Nilai sig(1-tailed) $=0,000<$ 0,05 memberi arti bahwa sig(1-tailed) $<\alpha$ yang menyebabkan ditolaknya $\mathrm{H}_{0}$ dan diterimanya $\mathrm{H}_{\mathrm{a}}$ yang berarti dapat disimpulkan bahwa kemampuan pemecahan masalah siswa sesudah penerapan model Project based learning lebih baik dibandingkan sebelum penerapan.

Analisis korelasi dilakukan untuk mengetahui tingkat keeratan hubungan antara kemampuan berpikir kreatif dan pemecahan masalah.Sebelum pengujian dilakukan terlebih dahulu data diuji normalitas dan homogenitasnya. Ringkasan hasil uji ditunjukan dalam Tabel 9.

Tabel 9. Hasil Uji Normalitas dan Homogenitas N-Gain

\begin{tabular}{|l|c|l|}
\hline Pengujian & Hasil Uji (sig) & Kesimpulan \\
\hline Normalitas N-gain Berpikir Kreatif & 0,200 & Normal \\
\hline $\begin{array}{l}\text { Normalitas N-Gain Pemecahan } \\
\text { Masalah }\end{array}$ & 0,200 & Normal \\
\hline Homogenitas & 0,107 & Homogen \\
\hline
\end{tabular}


Berdasarkan ringkasan hasil uji pada Tabel 9 dapat disimpulkan kedua skor N-Gain berdistribusi normal dan homogen sehingga pengujian dapat dilakukan dengan menggunakan regresi linear. Pengujian menggunakan bantuan software SPSS 22 dengan signifikan $\alpha=0,05$. Kriteria pengujian adalah jika Sig (2-tailed) > a maka $\mathrm{H}_{\mathrm{o}}$ diterima dan jika Sig (2-tailed) $<\alpha$ maka $\mathrm{H}_{\mathrm{o}}$ ditolak dan $\mathrm{H}_{\mathrm{a}}$ diterima. Ringkasan hasil pengujian ditunjukan dalam Tabel 10.

Tabel 10. Hasil Uji Perbedaan Kemampuan Pemecahan Masalah

\begin{tabular}{|l|l|r|r|}
\hline & & \multicolumn{1}{|c|}{ Gainmas } & \multicolumn{1}{|c|}{ Gainkrea } \\
\hline \multirow{5}{*}{ Gainmas } & Pearson correlation & 1 &, $479 * *$ \\
\cline { 2 - 4 } & Sig. (2-tailed) & &, 007 \\
\cline { 2 - 4 } & $\mathrm{N}$ & 30 & 30 \\
\hline \multirow{3}{*}{ Gainkrea } & Pearson correlation &, $479 * *$ & 1 \\
\cline { 2 - 4 } & Sig. (2-tailed) &, 007 & \\
\cline { 2 - 4 } & $\mathrm{N}$ & 30 & 30 \\
\hline \multirow{2}{*}{$* *$. Correlation is significant at the 0.01 level (2-tailed) } \\
\hline
\end{tabular}

Berdasarkan Tabel 10 dapat dilihat bahwa hasil uji menunjukkan nilai sig (2-tailed) sebesar 0,007 < 0,05 dengan tingkat korelasi positif sebesar 0,479 antara peningkatan kedua kemampuan tersebut. Nilai sig (2-tailed) $=0,007<0,05$ menunjukan bahwa hubungan tersebut signifikan. Dengan kata lain dapat dijelaskan bahwa peningkatan kemampuan berpikir kreatif berpengaruh positif terhadap peningkatan kemampuan pemecahan masalah demikian juga sebaliknya. Korelasi sebesar 0,479 menunjukan bahwa korelasi antara peningkatan kemampuan berpikir kreatif dan kemampuan pemecahan masalah termasuk dalam kategori cukup. Dengan merujuk pada kriteria pengujian maka hal tersebut menyebabkan ditolaknya $\mathrm{H}_{0}$ dan diterimanya $\mathrm{H}_{\mathrm{a}}$ yang berarti dapat disimpulkan bahwa terdapat hubungan yang positif dan signifikan antara peningkatan kemampuan berpikir kreatif dan pemecahan masalah siswa dalam pembelajaran dengan model Project based learning.

Sebagai uji lanjut untuk menguatkan kesimpulan tersebut dilakukan uji regresi linear. Uji regresi digunakan untuk melihat seberapa besar sumbangan (dukungan) nilai sebuah variabel terhadap variabel lainnya. 
Ringkasan hasil uji regresi linear peningkatan kemampuan berpikir kreatif terhadap kemampuan pemecahan masalah ditunjukkan pada Tabel 11.

Tabel 11. Ringkasan Uji Regresi Linear Peningkatan Kemampuan Berpikir Kreatif terhadap Kemampuan Pemecahan Masalah

\begin{tabular}{|c|c|r|r|r|r|r|}
\hline \multicolumn{2}{|c|}{} & \multicolumn{2}{|c|}{$\begin{array}{c}\text { Unstandardized } \\
\text { Coefficients }\end{array}$} & $\begin{array}{c}\text { Standardized } \\
\text { Coefficients }\end{array}$ & \multirow{2}{*}{ T } & \multirow{2}{*}{ Sig. } \\
\cline { 3 - 7 } & Model & B & $\begin{array}{c}\text { Std. } \\
\text { Error }\end{array}$ & \multicolumn{1}{|c|}{ Beta } & & \\
\hline 1 & (Constant) &, 528 &, 077 & & 6,877 &, 000 \\
\cline { 3 - 8 } & Gainkrea &, 336 &, 116 &, 479 & 2,887 &, 007 \\
\hline
\end{tabular}

a. Dependent variable: Gainmas

Berdasarkan Tabel 11 dapat dibuat persamaan regresi liniernya yaitu $\hat{Y}=0,528+0,336 \mathrm{X}, \mathrm{X}$ adalah nilai peningkatan kemampuan berpikir kreatif dan $\hat{Y}$ adalah peningkatan kemampuan pemecahan masalah. Hal ini menunjukan bahwa kemampuan berpikir kreatif meningkatkan kemampuan pemecahan masalah sebesar 0,336 atau 33,6\% dari nilai peningkatannya. Berikut disajikan ringkasan hasil uji seberapa besar sumbangan peningkatan kemampuan pemecahan masalah terhadap peningkatan kemampuan berpikir kreatif.

Tabel 12. Ringkasan Uji Regresi Linear Peningkatan Kemampuan Pemecahan Masalah terhadap Kemampuan Berpikir Kreatif

\begin{tabular}{|c|c|c|c|c|c|c|}
\hline & \multirow{2}{*}{ Model } & \multicolumn{2}{|c|}{$\begin{array}{l}\text { Unstandardized } \\
\text { Coefficients }\end{array}$} & \multirow{2}{*}{$\begin{array}{c}\begin{array}{c}\text { Standardized } \\
\text { Coefficients }\end{array} \\
\text { Beta }\end{array}$} & \multirow{2}{*}{$\mathbf{T}$} & \multirow{2}{*}{ Sig. } \\
\hline & & B & $\begin{array}{l}\text { Std. } \\
\text { Error }\end{array}$ & & & \\
\hline \multirow[t]{2}{*}{1} & (Constant) & 131 & 178 & & ,738 & ,467 \\
\hline & Gainmas & 683 & 236 & 479 & 2,887 & ,007 \\
\hline
\end{tabular}

Berdasarkan Tabel 12 dapat dibuat persamaan regresi liniernya yaitu $\hat{Y}=0,131+0,683 \mathrm{X}, \mathrm{X}$ adalah nilai peningkatan kemampuan pemecahan masalah dan $\hat{Y}$ adalah peningkatan kemampuan berpikir kreatif. Hal ini 
menunjukkan bahwa kemampuan pemecahan masalah meningkatkan kemampuan berpikir kreatif sebesar 0,683 atau $68,3 \%$ dari nilai peningkatannya.

Berdasarkan hasil regresi kedua kemampuan tersebut dapat dilihat bahwa kemampuan pemecahan masalah lebih berpengaruh terhadap peningkatan kemampuan berpikir kreatif dibandingkan kemampuan berpikir kreatif terhadap peningkatan kemampuan pemecahan masalah. Namun demikian berdasarkan analaisis terhadap hasil uji dapat disimpulkan bahwa peningkatan kemampuan berpikir kreatif dan peningkatan kemampuan pemecahan masalah saling mendukung dan memberikan pengaruh yang positip terhadap hasil belajar siswa.

Hasil penelitian ini diharapkan dapat memberi penjelasan mengenai hubungan dan pengaruh dari penerapan model PjBL terhadap peningkatan kemampuan berpikir kreatif dan pemecahan masalah.Hasil penelitian menunjukan bahwa kemampuan berpikir kreatif dan pemecahan masalah siswa menjadi lebih baik setelah pembelajaran dengan model PjBL. Keberhasilan siswa tidak terlepas dari model pembelajaran yang digunakan yaitu pembelajaran model Project based learning ( $\mathrm{PjBL}$ ). Masalah yang digunakan dalam pembelajaran $\mathrm{PjBL}$ berupa masalah kontekstual yang dapat melatih atau mengembangkan kemampuan siswa dalam berfikir kreatif dengan mengeksplorasi dan mengemukakan ide-ide matematis, serta mengidentifikasi dan menyelesaikan masalah yang diberikan. Rembely (2013) menyatakan bahwa project based activity yang dilakukan dalam pembelajaran dapat meningkatkan rasa ketertarikan siswa dalam memecahkan masalah sehingga berusaha memahami dan mencari cara penyelesaian masalah yang sesuai dengan kondisi yang ada.

Hasil penelitian juga menunjukkan bahwa terdapat korelasi yang positif antara peningkatan kemampuan berpikir kreatif dengan peningkatan kemampuan pemecahan masalah. Kedua kemampuan memberikan pengaruh yang positif bagi peningkatan kemampuan yang lainnya karena aktifitas dalam pembelajaran melalui masalah yang dikemas dalam bentuk kerja proyek memberikan pengalaman belajar yang menarik dan sekaligus meningkatkan kemampuan berpikir kreatif yang mendorong kemampuan siswa dalam memecahkan masalah. Hasil penelitian Mukhtamirin (2014) juga menyimpulkan bahwa penerapan 
model PjBL berpengaruh positif terhadap peningkatan kemampuan berpikir kreatif dan pemecahan masalah siswa. Serta penelitian yang dilakukan oleh Hidayah (2015) yang menyatakan bahwa pembelajaran dengan model Project based learning dapat meningkatkan kemampuan berpikir kreatif siswa sehigga sangat direkomendasikan dalam pembelajaran jika ingin meningkatkan kemampuan berpikir kreatif. Model PjBL dapat digunakan sebagai alternatif pembelajaran matematika untuk mengembangkan kemampuan berpikir kreatif dan pemecahan masalah siswa yang diharapkan dapat membuat perubahan bagi siswa Madrasah Tsanawiyah swasta sehingga memberikan hasil yang lebih optimal.

\section{Simpulan}

Berdasarkan hasil penelitian dan pembahasan penerapan model Project based learning ( $\mathrm{PjBL}$ ) untuk meningkatkan kemampuan berpikir kreatif dan pemecahan masalah diperoleh kesimpulan sebagai berikut:

1. Kemampuan berpikir kreatif siswa setelah pembelajaran dengan model project based learning lebih baik dari sebelum penerapan.

2. Kemampuan pemecahan masalah siswa setelah pembelajaran dengan model project based learning lebih baik dari sebelum penerapan.

3. Kemampuan berpikir kreatif memberikan pengaruh yang positif terhadap kemampuan pemecahan masalah.

\section{Daftar Pustaka}

Amalia, Y. (2014). Penerapan model eliciting activities untuk meningkatkan kemampuan berpikir kreatif matematis dan self-confidence siswa SMA.Tesis. Universitas Syiah Kuala.

Depdiknas. (2006). Permendiknas No. 22 Tahun 2006 tentang standarisasi sekolah dasar dan menengah. Jakarta: Depdiknas.

Dwijanto. (2007). Pengaruh pembelajaran berbasis masalah berbantuan komputer terhadap pencapaian kemampuan pemecahan masalah dan berpikir kreatif matematik. Disertasi. Universitas Pendidikan Indonesia

Hidayah, A. (2015). Effect of project based learning approach contextual to creativity of student of madrasah. Diakses di http://icmseunnes.com/2015/wp-content/uploads/2016/03/73_PE.pdf. 
Husna. (2013). Peningkatan kemampuan pemecahan masalah dan komunikasi matematis siswa sekolah menengah pertama melalui pembelajaran kooperatif tipe think-pair-share (TPS). Tesis Magister Pendidikan Matematika. Unsyiah Banda Aceh.

Mukhtamirin. (2014). Pengaruh model project based learning terhadap kemampuan berpikir kreatif dan kemampuan pemecahan masalah matematika bagi siswa kelas IX SMPN 18 kota Bengkulu. Diakses di http://repository.unib.ac.id/id/eprint/9648

NCTM. (2000). Principles and standards for school mathematics.Reston, VA: NCTM Publications

Polya, G. (1985). How to solve it. A new aspect of mathematical method $\left(2^{\text {nd }}\right.$ edition). Princeton, New Jersey: Princeton University Press.

Rembely. (2013). Project-based activity: Root of research and creative thinking. International Education Studies, 6 (6), 66-71

Sari, A., Ikhsan, M., \& Saminan, S. (2017). Proses berpikir kreatif siswa dalam memecahkan masalah matematika berdasarkan model Wallas. Beta Jurnal Tadris Matematika, 10(1), 18-32. doi:10.20414/betajtm.v10i1.102

Sembiring, R.K., Hadi, S., \& Dolk, M. (2008). Reforming mathematics learning in Indonesian classroom through RME.ZDM Mathematics Education, 40, 927-939.

Siswono, T. Y. E. (2008). Model Pembelajaran Matematika Berbasis Pengajuan dan Pemecahan Masalah untuk Meningkatkan Kemampuan Berpikir Kreatif. Surabaya: Unesa University Press

Siswoyuono, A., \& Susilo, B. (2016).Komparasi pembelajaran SAVI dan REACT pada kemampuan pemecahan masalah siswa kelas-VIII materi kubus dan balok.Beta Jurnal Tadris Matematika, 9(1), 15-33. doi:10.20414/betajtm.v9i1.3

Sumarmo, U. (2000). Pengembangan model pembelajaran matematika untuk meningkatkan kemampuan intelektual tingkat tinggi siswa sekolah dasar. Laporan Penelitian Hibah Bersaing. Bandung: Universitas Pendidikan Indonesia

Sundayana, R. (2010). Statistik penelitian pendidikan. Garut: STKIP Garut Press.

Tasni, N., \& Susanti, E. (2017). Membangun koneksi matematis siswa dalam pemecahan masalah verbal. Beta Jurnal Tadris Matematika, 10(1), 103116. doi:10.20414/betajtm.v10i1.108

The George Lucas Educational Foundation. (2005). Instructional module project based learning. Diakses di http://www.edutopia.org/modules/PBL/whatpbl.php.

Thomas, J.W. (2000). A review of research on project-based learning. California: The Autodesk foundation. Diakses di http://www.bobpearlman.org/BestPractices/PBL_Research.pdf. 
Wahyu, K. (2015, Nopember). Changing mathematics classroom setting: Looking into students' response and performance in learning. Paper presented at International Conference on Mathematics, Science and Education Mataram University, Mataram - Indonesia.

Yunianta, T.N.H., Rochmad \& Rusilowati, A. (2012). Kemampuan berpikir kreatif siswa pada implementasi project based learning dengan peer and self-assessment untuk materi segiempat kelas VII SMPN RSBI 1 Juwana di Kabupaten Pati. Makalah dipresentasikan dalam Seminar Nasional Matematika dan Pendidikan Matematika tanggal 10 November 2012 di Jurusan Pendidikan Matematika FMIPA UNY. 